\title{
Where is QDA hiding? An analysis of the discoverability of qualitative research support on academic library websites \\ Jonathan Cain ${ }^{1}$, Liz Cooper ${ }^{2}$, Sarah DeMott ${ }^{3}$, Alesia Montgomery ${ }^{4}$
}

\begin{abstract}
This study explores the discoverability of qualitative research support services, using a purposive sample of academic library websites $(n=95)$. These services were hard to find on most of the websites in our sample. In this paper, we outline the site characteristics that make discoverability easy or hard. Previous studies on qualitative resources at academic libraries have not addressed this topic. Our study fills this gap in the literature. Our aim is to provide information that can help libraries to improve the visibility of their resources for qualitative researchers and their students.
\end{abstract}

\section{Keywords}

Qualitative Research Support, Discoverability, CAQDAS, Research Guides, Academic Libraries

\section{Introduction}

In the world of data librarianship, quantitative data remains sovereign. Whenever there is a data science initiative on a U.S. campus, it is the quantitative courses, procedures, and tools that administrators offer as illustrations of data science and data research. When administrators allocate funds for data analysis tools, often, qualitative tools are left by the wayside. However, as data science matures, researchers increasingly strive for holistic design, participatory research, and mixed methods-approaches that include qualitative techniques. Thus, qualitative data analysis (QDA) has become more prominent in research projects, and qualitative digital tools, methods, and sources have grown in importance for scholars in the humanities, sciences, social sciences, and the professions (engineering, law, medicine).

As researchers acknowledge the value of qualitative data, we must ask how libraries are meeting the demand for qualitative research support services. To address this concern, our six-member teamcomposed of academic librarians, research specialists, social scientists, and their overlap-began a project to evaluate the availability of these services. Initially, we intended to compile a web directory of links to library qualitative services, with the aim of informing our colleagues in the IASSIST Qualitative Social Science \& Humanities Data Interest Group (QSSHDIG). IASSIST is "an international organization of professionals working in and with information technology and data services to support research and teaching. ${ }^{\prime 5}$ However, we soon found that it was hard to find qualitative services on library websites, even when we knew that particular libraries did offer these services. We asked ourselves: "Where is QDA hiding?!" Four members of our original team shifted our focus to conduct an exploratory study of the discoverability of qualitative services on academic library websites.

\section{Literature Review}

Within the social sciences, there are various definitions of qualitative research and data. In this paper, we define "qualitative research" as the naturalistic, interpretive study of social meanings and processes that uses techniques such as in-depth interviews, observations, and textual analysis. We describe "qualitative data" as the work material of researchers who use qualitative 
methods. Qualitative data is often called "unstructured" data-for example, the interview transcripts, field notes, and neighborhood photos of qualitative researchers-in contrast to the tabular, numerical, "structured" data of quantitative researchers.

Since the late twentieth century, qualitative researchers have increasingly digitized and archived their data for secondary analysis, and social media (e.g., Twitter, Facebook) have become novel sources of data. In this era of "big data," both quantitative and qualitative researchers sometimes analyze massive assemblages of unstructured data-the kind of material that was once solely the domain of qualitative researchers-and they sometimes engage in mixed methods research (Boyd and Crawford, 2012; Davidson et al., 2018; Delyser and Sui, 2013; McFarland et al., 2016). Thus, there is an overlap in the data, data analysis tools, and data management and archiving support services that qualitative and quantitative researchers need. Yet even when qualitative and quantitative researchers use the same data, tools, and archives, they still often maintain distinct epistemological assumptions, research terminology, analytical approaches, and data reuse concerns. Given the dominance of quantitative research in the social sciences, the challenge for social science librarians is to make their services available and discoverable in ways that respect the unique needs, language, and concerns of qualitative researchers.

Most literature on data services focuses on the needs of quantitative researchers (e.g., Geraci et al., 2012). Surveys of data services at academic libraries sometimes contain an item about qualitative data support (Tenopir et al., 2017), but few studies focus on qualitative data services (Corti, 2000; Mannheimer et al., 2018). An excellent example of this latter work is Mandy Swygart-Hobaugh's (2016) study of the qualitative data services offered by academic libraries. Swygart-Hobaugh outlines the types of services that could be provided to qualitative researchers across the data life cycle:

- During the first stage-discovery and planning-librarians could help qualitative researchers find information about archived materials for secondary analysis and they could inform researchers about project documentation procedures.

- During the intermediate stages - data collection, processing, and analysis-librarians could provide services such as helping researchers learn to use qualitative data analysis software.

- During the final stages-research dissemination and long-term management-librarians could help qualitative researchers to archive and share their data.

After presenting this outline, Swygart-Hobaugh describes the types of services that academic libraries do provide, based on her analyses of (1) academic librarian job postings in the IASSIST repository ( $n=148),(2)$ an online survey of academic librarians ( $n=112)$, and (3) qualitative research guides on academic websites $(n=53)$. She found that the academic libraries in her sample emphasize quantitative data support much more than qualitative data support. Most IASSIST job postings ( 83 out of 148) mention quantitative expectations (for example, statistical skills) while few (22 out of 148) mention qualitative expectations (for example, knowledge of qualitative analysis software). Few social science librarians report providing services specifically targeted to qualitative researchers, and few academic library websites link to qualitative research resources. Based on her findings, Swygart-Hobaugh urges the expansion of qualitative data support services, especially at universities in which a significant number of faculty and graduate students do qualitative research. 
As academic libraries respond to researcher demand by expanding their research support services (Kennan et al., 2014), they must carefully plan ways to make their qualitative research services visible. Our literature review uncovered no studies that focus on the discoverability of qualitative research services on academic library websites. There are usability studies of academic library websites (Comeaux, 2017; Ridha, 2018), and there are recommendations for making data discoverable (MacMillan, 2014), but there does not appear to be research that specifically focuses on the visibility of qualitative research services on library websites. Our study fills this gap in the literature. If qualitative researchers cannot find these services on library websites - or if the language framing these services seems tailored to quantitative researchers--then qualitative researchers may not take advantage of these services, even when they are available. Discoverability is also important in supporting a community of practice among those of us who provide services to qualitative researchers: being able to easily find the qualitative resources offered by our colleagues at other institutions may help us to forge ties with and learn from each other.

\section{Methods}

For our exploratory study, we selected a diverse sample of U.S. academic libraries ( $n=95)$ at public and private institutions that vary in size and resources (see Appendix). We used the list of American Research Libraries (ARL) to help us identify institutions. ${ }^{6}$ However, we did not include all of the ARL institutions, and a few institutions in our sample are not ARL members. After we chose the institutions for the study, we assigned a set of roughly 20 institutions to each member of our research team. None of us reviewed her or his home institution. We focused our assessment on the degree to which it was easy to find the range of qualitative services that faculty and students might use across the data life cycle on the library websites. As part of this evaluation, we examined qualities such as the location of qualitative research resources and the types of data support services offered (for example, software tutorials and workshops, data management tools).

\section{Discussion}

It is hard to find qualitative services on the websites of most libraries in our sample. Perhaps many of these libraries do not provide these services, which would be in line with the findings of SwygartHobaugh's (2016) study. Yet, in some cases, we eventually found mention of qualitative services offered by the libraries after trial-and-error searches using various search terms. We often found these services by entering the brand names of popular qualitative software, such as NVivo, ATLAS.ti, Dedoose, and MAXQDA. Approximately half of our sample references at least one qualitative software brand. Libraries mention, for example, that a brand is available on campus computers and/or that staff are available to provide software training.

It is problematic that, for some libraries, the only way to find out about their qualitative services is to enter the name of a proprietary software. Their patrons may not know these brand names, and they may not even know much about qualitative software. Mention of these brands is sometimes buried on pages that list quantitative software and do not include the word "qualitative." It is also problematic that, for some libraries, data services that qualitative researchers might need-for instance, help with archiving their research or learning a programming language such as Python that could be used for web scraping - can be found by entering the term "quantitative" on the library's homepage but not "qualitative." It was much easier to find mention of support across the data lifecycle for quantitative research. When support for qualitative software was mentioned on a library website, it was rarely linked to data management webpages, and these webpages tended not to 
address the unique needs of qualitative researchers. In some cases, information about qualitative services was isolated from other data services pages on the library website-for example, the information might reside on a LibGuide for a course or discipline. In other cases, we found qualitative resources scattered across institutional silos in and beyond the library, such as campus units that support transcription tools or audio and video recording. It seems likely that these qualitative resources have been developed independently across units, with little collaboration or communication, and thus they have not been showcased as a set. These silos include data services, tech support, digital scholarship, digital humanities, and GIS services.

In contrast, we found that library websites that make it easy to find qualitative services tend to share the following four characteristics:

(1) Data services are prominently featured on the library home page.

(2) Links to data services are integrated into the top level of the library website's menus.

- Data services webpages are accessible within 1-2 clicks.

- Users do not have to search through the site.

(3) Labels for data services are intuitive and include the terminology of qualitative researchers-novice users of qualitative services do not have to guess terms (e.g., software brand names) for finding resources.

(4) There is one integrated website for all data services support.

- Qualitative and quantitative data support are both explicitly mentioned and supported.

- Services across the data lifecycle are outlined in one place (e.g., data discovery, data analysis including software workshops, data management).

- Any related units or services that provide support are linked back to this main page (including any research guides).

- The structure of the data services website is based on user needs, not the organizational structure of data services.

Below we illustrate the qualities of websites that make it easy to find data services on their home pages and that have integrated data services websites that mention qualitative services (see Figures 1 and 2). 


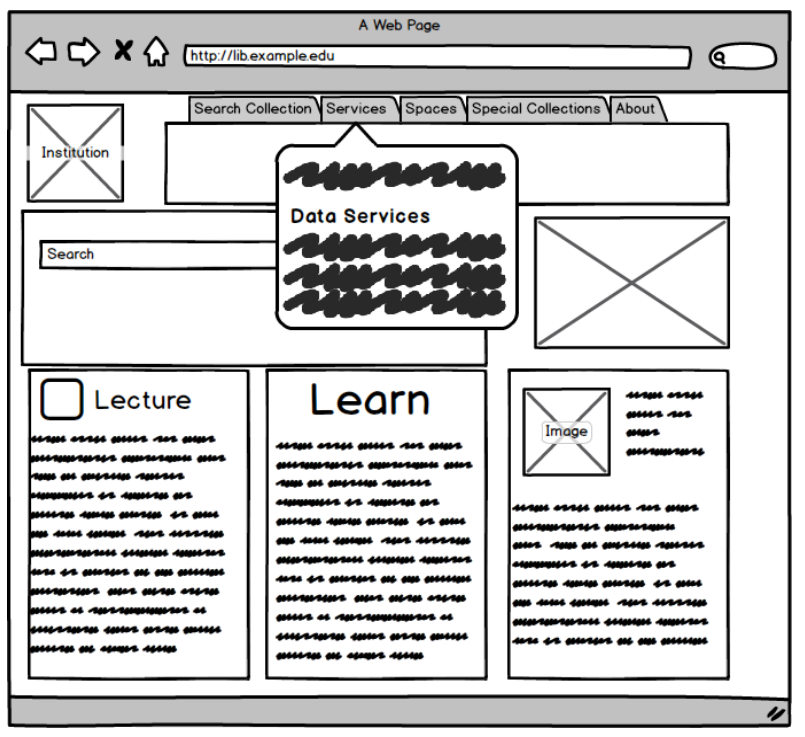

Figure 1: Example Library Home Page: One Click to Finding Qualitative Resources

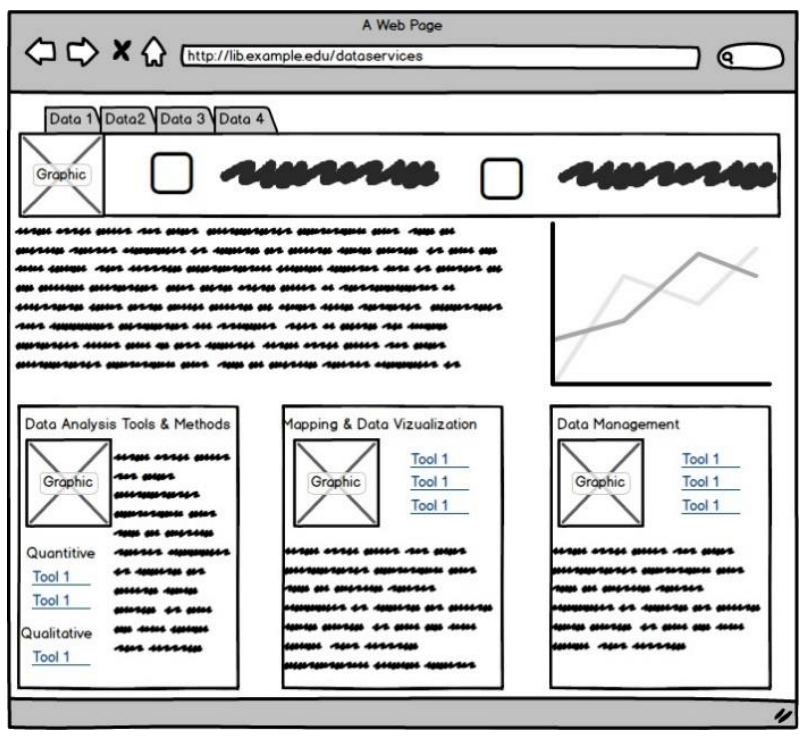

Figure 2: Example Integrated Data Services Page

It is important to note that qualitative data services are rapidly evolving and that some institutions already may be taking steps to improve the visibility of these services and to coordinate their delivery. Over the course of our study, as we revisited websites, we noticed that some libraries with hard-to-find qualitative resources have greatly improved their discoverability: for example, one library has made its qualitative services discoverable by bringing them out from behind a firewall. From the library's homepage, entering the term "qualitative" now returns a treasure trove of resources, including links to qualitative software, a software guide, staff, a user group, and a relevant database.

\section{Conclusion}

Currently, finding information about qualitative research support on library websites is difficult. Although on many campuses and in many disciplines support for qualitative research is secondary to 
support for quantitative research, as more researchers begin to work with unstructured data and others strive for more holistic design, the demand for qualitative research continues to increase. Libraries wanting to provide robust support for data services would do well to consider not only Swygart-Hobaugh's 2016 recommendations on types of qualitative support libraries might offer across the data lifecycle, but also to dedicate time and resources to ensuring the discoverability of these services on their websites.

\section{References}

Al-Qallaf, C.L. \& Ridha, A. (2018), "A Comprehensive Analysis of Academic Library Websites: Design, Navigation, Content, Services, and Web 2.0 Tools", International Information \& Library Review, pp. 1-14, available from https://doi.org/10.1080/10572317.2018.1467166 (accessed 29 January 2019).

Boyd, D. \& Crawford, K. (2012), "Critical Questions for Big Data”, Information, Communication \& Society, vol. 15, no. 5, pp. 662-679, available from https://doi.org/10.1080/1369118X.2012.678878 (accessed 12 February 2019).

Comeaux, D.J. (2017), "Web Design Trends in Academic Libraries-A Longitudinal Study", Journal of Web Librarianship, vol. 11, no. 1, pp. 1-15, available from https://doi.org/10.1080/19322909.2016.1230031 (accessed 29 January 2019).

Corti, L. (2000), "Progress and Problems of Preserving and Providing Access to Qualitative Data for Social Research-The International Picture of an Emerging Culture", Forum Qualitative Sozialforschung / Forum: Qualitative Social Research, vol. 1, no. 3, available from http://www.qualitative-research.net/index.php/fqs/article/view/1019 (accessed 12 February 2019).

Davidson, E., Edwards, R., Jamieson, L. \& Weller, S. (2018), "Big Data, Qualitative Style: A Breadthand-Depth Method for Working with Large Amounts of Secondary Qualitative Data", Quality \& Quantity, available from http://link.springer.com/10.1007/s11135-018-0757-y (accessed 3 October 2018).

DeLyser, D. \& Sui, D. (2013), “Crossing the Qualitative-Quantitative Divide II: Inventive Approaches to Big Data, Mobile Methods, and Rhythmanalysis", Progress in Human Geography, vol. 37, no. 2, pp. 293-305, available from http://journals.sagepub.com/doi/10.1177/0309132512444063 (accessed 1 February 2019).

Geraci, D., Humphrey, C. \& Jacobs, J. (2012), Data Basics: An Introductory Text, available from http://3stages.org/class/2012/pdf/data basics 2012.pdf.

Kennan, M.A., Corrall, S. \& Afzal, W. (2014), “'Making Space' in Practice and Education: Research Support Services in Academic Libraries", Library Management, vol. 35, no. 8/9, pp. 666-683, available from http://www.emeraldinsight.com/doi/10.1108/LM-03-2014-0037 (accessed 31 January 2019). 
MacMillan, D. (2014), "Data Sharing and Discovery: What Librarians Need to Know", The Journal of Academic Librarianship, vol. 40, no. 5, pp. 541-549, available from http://www.sciencedirect.com/science/article/pii/S0099133314000950 (accessed 11 February 2019).

Mannheimer, S., Pienta, A., Kirilova, D., Elman, C. \& Wutich, A. (2018), “Qualitative Data Sharing: Data Repositories and Academic Libraries as Key Partners in Addressing Challenges", American Behavioral Scientist, available from https://par.nsf.gov/biblio/10062050-qualitative-data-sharingdata-repositories-academic-libraries-key-partners-addressing-challenges (accessed 12 February 2019).

McFarland, D.A., Lewis, K. \& Goldberg, A. (2016), "Sociology in the Era of Big Data: The Ascent of Forensic Social Science", The American Sociologist, vol. 47, no. 1, pp. 12-35, available from https://doi.org/10.1007/s12108-015-9291-8 (accessed 1 February 2019).

Swygart-Hobaugh, A. (2016), "Qualitative Research and Data Support: The Jan Brady of Social Sciences Data Services?”, in L. M. Kellam \& Thompson, Kristi (eds.). Databrarianship: The Academic Data Librarian in Theory and Practice, pp. 153-178, American Library Association, Chicago, IL, available from https://scholarworks.gsu.edu/univ lib facpub/128.

Tenopir, C., Talja, S., Horstmann, W., Late, E., Hughes, D., Pollock, D., Schmidt, B., Baird, L., Sandusky, R.J. \& Allard, S. (2017), "Research Data Services in European Academic Research Libraries", Liber Quarterly, vol. 27, no. 1, pp. 23-44, available from https://www.liberquarterly.eu/article/10.18352/lq.10180 (accessed 1 February 2019).

\section{Appendix: List of Libraries}

1. University at Buffalo, SUNY, Libraries

2. University of Calgary - Libraries and Cultural Resources

3. University of California, Berkeley Library

4. University of California, Davis Library

5. University of California, Irvine Libraries

6. UCLA Library

7. University of California, Riverside Library

8. UC San Diego Library

9. University of California, Santa Barbara Libraries

10. Case Western Reserve University Libraries

11. The University of Chicago Library

12. University of Cincinnati Libraries

13. University of Colorado Boulder Libraries

14. Colorado State University Libraries

15. Columbia University Libraries

16. University of Connecticut Libraries

17. Cornell University Library

18. Dartmouth College Library

19. University of Delaware Library

20. Duke University Libraries

21. Emory University Libraries 
22. University of Florida Libraries

23. Florida State University Libraries

24. The George Washington University Library

25. Georgetown University Library

26. University of Georgia Libraries

27. Georgia Institute of Technology Library

28. Georgia State University

29. University of Guelph Library

30. Harvard Library

31. University of Hawai'i at Mānoa Library

32. University of Houston Libraries

33. Howard University Libraries

34. University of Illinois at Chicago Library

35. University of Illinois at Urbana-Champaign Library

36. Indiana University Libraries Bloomington

37. The University of lowa Libraries

38. Iowa State University Library

39. Johns Hopkins University Libraries

40. University of Kansas Libraries

41. Kent State University Libraries

42. University of Kentucky Libraries

43. University of Louisville Libraries

44. McGill University Library

45. McMaster University Libraries

46. University of Minnesota Libraries

47. New York Public Library

48. New York University Libraries

49. University of North Carolina at Chapel Hill Libraries

50. North Carolina State University Libraries

51. Northwestern University Library

52. University of Notre Dame Libraries

53. The Ohio State University Libraries

54. Ohio University Libraries

55. University of Oklahoma Libraries

56. Oklahoma State University Library

57. University of Oregon Libraries

58. University of Ottawa Library

59. University of Pennsylvania Libraries

60. Pennsylvania State University Libraries

61. University of Pittsburgh Libraries

62. Princeton University Library

63. Purdue University Libraries

64. Queen's University Library

65. Rice University Library

66. University of Rochester Libraries

67. Rutgers University Libraries

68. University of Saskatchewan Library

69. Simon Fraser University Library

70. Smithsonian Libraries

71. University of South Carolina Libraries

72. University of Southern California Libraries 
73. Stanford University Libraries

74. Stony Brook University, SUNY, Libraries

75. Syracuse University Libraries

76. Temple University Libraries

77. University of Tennessee, Knoxville, Libraries

78. University of Texas Libraries

79. Texas A\&M University Libraries

80. Texas Tech University Libraries

81. University of Toronto Libraries

82. Tulane University Library

83. University of Utah Library

84. Vanderbilt University Library

85. University of Virginia Library

86. Virginia Tech Libraries

87. University of Washington Libraries

88. Washington State University Libraries

89. Washington University in St. Louis Libraries

90. University of Waterloo Library

91. Wayne State University Libraries

92. Western University Libraries

93. University of Wisconsin-Madison Libraries

94. Yale University Library

95. York University Libraries

\section{Endnotes}

${ }^{1}$ Jonathan Cain, Head, Data Services \& Librarian for Planning Public Policy and Management University of Oregon, jocain@uoregon.edu

${ }^{2}$ Liz Cooper, Social Sciences Librarian, University of New Mexico, cooperliz@unm.edu

${ }^{3}$ Sarah Demott, Research Specialist, Data Services, New York University, sarah.demott@nyu.edu

${ }^{4}$ Alesia Montgomery, Subject Specialist for Sociology, Psychology, \& Qualitative Data Stanford University, alesiam@stanford.edu

${ }^{5}$ A description of IASSIST can be found at https://iassistdata.org

${ }^{6}$ Association of Research Libraries Member List, https://www.arl.org/membership/list-of-arl-members, accessed February 10, 2019 